\title{
Analisis Kualitas Sumber Daya Manusia dalam Menekan Angka Kemiskinan
}

(Studi Kasus Desa Petunang Kabupaten Musi Rawas)

\section{Ronal Aprianto}

Sekolah Tinggi Ilmu Ekonomi Musi Rawas

ronal.gbs@gmail.com

\section{Irma Idayati}

Sekolah Tinggi Ilmu Ekonomi Musi Rawas Irmaidayati719@gmail.com

\begin{abstract}
Abstrak Penelitian ini bertujuan untuk menganalisis kualitas sumber daya manusia dalam menekan angka kemiskinan Desa Petunang Kab. Musi Rawas. Penelitian ini menggunakan penelitian kualitatif hasil dari penelitian menunjukan dapat disimpulkan bahwa, kualitas sumber daya manusia dalam menekan angka kemiskinan di Desa Petunang Kab. Musi Rawas adalah bahwa kualitas sumber daya manusia penduduk miskin Desa Petunang memang sangatlah buruk untuk dapat menekan angka kemiskinan yang terjadi di Desa Petunang. Hal ini terlihat di data yang menyatakan jumlah sarana kesehatan hanya memiliki 1 pustu bantuan desa petunang, jumlah sarana pendidikan hanya mempunyai SD 1, jenis kegiatan/organisasi keagamaan hanya mempunyai 1 kegiatan 1 pengajian mingguan wanita, jumlah penduduk beragama 2884 yang beragama islam, yang masyarakat miskin berjumlah 444 jiwa dan masyarakat miskin yang pendidikan SD sebesar 395 jiwa dengan $88,9 \%$, SMP 46 jiwa dengan 10,3\% dan SMA 3 jiwa dengan $0,8 \%$. Dan untuk pendapatan warga miskin Desa Petunang yang pendapatan dibawah 1.000 .000 berjumlah 83 jiwa dengan $18,7 \%$, pendapatan 1.000.000-1.500.000 berjumlah 361 jiwa dengan $81,3 \%$, dan yang pendapatannya diatas 1.500 .000 tidak ada. Untuk pengeluaran warga miskin Desa Petunang dibawah 1.000.000 sebanyak 21 jiwa dengan $4,8 \%$, pengeluaran 1.000.0001.500.000 sebanyak 417 jiwa dengan $94 \%$ dan pengeluaran diatas 1.500.000 sebanyak 6 jiwa dengan 0,2\%. Hal ini lah yang menyebabkan kualitas sumber daya manusia Desa Petunang Kab. Musi Rawas sangat buruk untuk menekan angka kemiskinan yang ada di Desa Petunang Kab. Musi Rawas
\end{abstract}

Kata Kunci Kualitas Sumber Daya Manusia, Angka Kemiskinan, Desa Petunang 


\section{PENDAHULUAN}

\subsection{Latar Belakang Masalah}

Kemiskinan merupakan salah satu masalah serius dalam proses pembangunan nasional di indonesia. Masalah ini seolah-olah tidak dapat dituntaskan secara serius, padahal upaya pemerintah telah memperkanalkan berbagai paket dan program yang melibatkan sejumlah pakar kemiskinan nasional dan internasional. Hakekatnya belum ada berkelanjutan (sustainability) sistem penanganan kemiskinan baik dalam satu rezim kekuasaan maupun pada saat peralihan rezim.

Setiap negara akan berusaha keras untuk menurunkan angka kemiskinan dengan meingkatkan sumber daya manusiakualitas sumber daya manusai yang buruk akan mengakibatkan angka kemiskinan meningkat dalam sebuah negara.kualitas sumber daya manusia juga memegang peranan penting dalam menekan angka kemiskinan. Menurut Salim (2014 : 2) mengemukakan kualitas sumber daya manusia sebagai berikut : kualitas sumber daya manusia adalah nilai dari pelaku seseorang dalam mempertanggung jawabkan semua perbuatannya baik dalam kehidupan pribadi maupun kehidupan bermasyarakat dan berbangsa.

Menurut Sharp (dalam Jonaidi 2013 : 142) penyebab kemiskinan di pandang dari segi ekonomi adalah akibat dari rendahnya kualitas sumber daya manusia. Peningkatan kualitas sumber daya manusia tercermin dalam berbagai aspek bidang antara lain : (1) Bidang pendidikan, yaitu melalui peningkatan pendidikan yang memerhatikan kebutuhan tenaga kerja sesuai dengan dinamika dan permintaan pasar (drive demand) serta arah dan sasaran pembangunan ekonomi di masa mendatang; (2) Bidang kesehatan, yaitu melalui peningkatann budaya hidup sehat, penyediaan sarana dan prasarana, obat-obatan, memperluas akses (cakupan) kesempatan dan mutu pelayanan kesehatan terutama jaminan kesehatan kepada penduduk miskin dan daerah terpencil; (3) Bidang pengetasan kemiskinan, yaitu melalui peningkatan keterampilan praktis, menumbuhkan sikap produktif, seta mendorong semangat kemandirian dan kerja sama (gotong royong); (4) Bidang kependudukan, yaitu melalui kesadaran melaksanakan program gerakan keluarga berencana untuk menekan laju pertumbuhan penduduk serta meningkatkan pemerataan penyebaran penduduk untuk keseimbangan geopolitik antara lain melalui program transmisi dan pembangunan industri di pedesaan (Mulyadi, $2014: 2-3$ ).

Dewasa ini kemiskinan pedesaan menjadi masalah utama dalam proses pelaksanaan pembangunan di daerah pedesaan, karena sebagian besar pendudukmiskin tinggal di daerah pedesaan dan karakteristik penyebab kemiskinan struktural yang dialami sangat banyak.Desa petunang merupakan desa yang cukup luas wilayahnya, dengan penduduk yang berjumlah 2884 jiwa dan tersebar di 8 dusun dan jumlah penduduk miskin desa petunang berjumlah 444 jiwa yang tersebar di 8 dusun dan masih banyak penduduk miskin yang berpendidikan SD sebanyak 395 jiwa yang SMP sebanyak 46 jiwa dan yang SMA sebanyak 3 jiwa. Seperti dijelaskan sebelumnya bahwa kualitas sumber daya manusia yang buruk akan mengakibatkan angka kemiskinan meningkat.Secara teoritis sumber daya manusia yang berada di desa petunang sangat buruk, hal ini mengakibatkan tingginya angka kemiskinan. Terlihat dalam data kependudukan 
Kecamatan Tuah Negeri bahwa terdapat 1845 jiwa yang tercatat sebagai pekerja di Desa Petunang. Artinya terdapat hampir 1.041 jiwa yang tidak bekerja, hal ini akan berdampak pada rendahnya pendapatan perkapita. Pendapatan perkapita mencerminkan tingkat kemakmuran suatu negara. Pendapatan perkapita yang rendah mengisyaratkan tingginya angka kemiskinan dalam suatu wilayah.

\section{Fokus dan subfokus penelitian}

Penelitian ini berfokus pada penekanan angka kemiskinan di desa petunang kabupaten musi rawas, sedangkan sub fokus penelitian ini dapat dilihat atau dianalisis dengan melihat variable kualitas sumber daya manusia. Data yang di analisis antara lain : 1) Data penduduk desa petunang, 2) Data penerima raskin, 3) Data status pekerjaan desa petunang, 4) Data jenis pekerjaan desa petunang dan 5) Data jumlah kelahiran dan kematian desa petunang.

\section{TINJAUAN PUSTAKA}

\subsection{Pengertian Kualitas Sumber Daya Manusia.}

Menurut Salim (2017 : 2) mengemukakan pengertian kualitas sumber daya manusia adalah nilai dari prilaku seseorang dalam pertanggung jawaban semua perbuatannya baik dalam kehidupan pribadi maupun kehidupan bermasyarakat. Menurut Soekidjo (dalam Anonim 2017 : 2) menyatakan kualitas sumber daya manusia menyangkut dua aspek, yaitu aspek fiisik (kualitas fisik) dan aspek non fisik ( kualitas nonfisik) yang menyangkut kemampuan bekerja, berfikir dan keterampilan-keterampilan lain.

Menurut Ndraha (2015 : 42) mengatakan bahwa kualitas sumber daya manusia adalah sumber daya manusia yang mampu menciptakan bukan saja nilai komparatif, tetapi juga nilai kompetitif, generatifinovatif dengan menggunakan energi tertinggi seperti intelligence, creativity, dan imagination, tidak lagi sematamata menggunakan energi kasar seperti bahan mentah, lahan, air, energi, otot, dan sebagainya.

\subsection{Indikator Kualitas Sumber Daya Manusia}

Menurut Sudarwan Danim dalam bukunya "Transformasi Sumber Daya Manusia"beliau mengatakan bahwa indikator dari kualitas sumber daya manusia adalah sebagai berikut:

1) Kualitas fisik dan kesehatan;

2) Kualitas intelektual (pengetahuan dan keterampilan);

3) Kualitas spiritual (kejuangan).

\subsection{Faktor-Faktor Yang Mempengaruhi Kualitas Sumber Daya Manusia}

1) Pendidikan dan Latihan Menghasilkan tenaga kerja yang lebih baik kualitasnya dan meningkatkan produktivitas kerja.

2) Gizi dan kesehatan masyarakat keadaan gizi dan kesehatan masyarakat sangat mempengaruhi kualitas Sumber Daya Manusia

3) Kondisi lingkungan dan sosial budaya Kondisi hidup yang berkualitas rendah dengan berbagai pencemaran dan semangat kerja yang rendah serta 
masyarakat yang merasa tidak menikmati hasil pekerjaan secara adil akan menurunkan kualitas kerja.

4)

\subsection{Pengertian Kemiskinan}

Supriatna (dalam Kadji 2017 : 1) menyatakan bahwa kemiskinan adalah situasi yang serba terbatas yang terjadi bukan kehendak orang yang bersangkutan. Menurut kotze (Dalam Kadji 2017 : 1) menyatakan bahwa masyarakat miskin memiliki kemampuan yang relatif baik untuk memperoleh sumber melalui kesempatan yang ada.

\subsubsection{Indikator kemiskinan}

Menurut Lincolin Arsyad (2016 : 303), ada beberapa macam ukuran yang seringkali digunakan sebagai indikator kemiskinan antara lain :

1) Tingkat konsumsi beras;

2) Tingkat pendapatan;

3) Indeks kesejahteraan rakyat;

4) Indeks kemiskinan manusia.

\subsubsection{Faktor-Faktor Yang Mempengaruhi Kemiskinan}

Menurut Sharp et al. (Dalam Rakhmawati 2017 : 1), kemiskinan terjadi dikarenakan beberapa sebab yaitu:

1) Rendahnya kualitas angkatan kerja;

2) Akses yang sulit terhadap kepemilikan modal;

3) Rendahnya masyarakat terhadap penguasaan teknologi;

4) Penggunaan sumber daya yang tidak efisien;

5) Tingginya pertumbuhan penduduk.

\section{METODELOGI PENELITIAN}

\subsection{Rancangan penelitian}

Rancangan penelitian dalam penelitian ini yaitu untuk mengidentifikasi masalah kualitas sumber daya manusia dalam menekan angka kemiskinan (studi kasus desa petunang kab. Musi rawas) dimana dalam penelitian ini peneliti menggunakan metode penelitian kualitatif metode penelitian kualitatif adalah metode penelitian yang berlandaskan pada filsafat postpositivisme, digunakan untuk meneliti pada kondisi objek yang ilmiah, (sebagai lawannya adalah eksperimen) dimana peneliti adalah instrumen kunci, teknik pengumpulan data dilakukan secara triangulasi (gabungan), analisis data bersifat induktif/kualitatif, dan hasil penelitian kualitatif lebih menekan makna dari pada generalisasi Sugiyono (2014:9).

\subsection{Latar penelitian}

Latar tempat penelitian ini adalah di desa petunang yang berkembang untuk mensejahterakan warganya yang berjumlah 2819 jiwa dengan KK 782 kepala keluarga yang mayoritas mempunyai pekerjaan sebagai petani karet, dengan penghasilan yang tidak tentu setiap harinya. 


\subsection{Prosedur penelitian.}

Prosedur Penelitian ini mendeskripsikan dan menganalisa secara dalam mengenai kualitas sumber daya manusia dalam menekan angka kemiskinan desa petunang kabupaten musi rawas. Prosedur penelitian menggunakan penelitian deskriftip kualitatif merupakan salah satu dari jenis penelitian yang termasuk dalam jenis penelitian kualitatif. Adapun tujuan dari penelitian ini adalah untuk mengungkapkan kejadian atau fakta, keadaan, fenomena, variabel dan keadaan yang terjadi saat penelitian berlangsung dengan menyuguhkan apa yang sebenarnya terjadi.

\subsection{Sumber data}

Menurut Masruroh (2013) sumber data adalah segala sesuatu yang dapat memberikan informasi mengenai data berdasarkan sumbernya, data dibedakan menjadi dua yaitu :

a. Data primer yaitu data yang buat oleh peneliti untuk maksud khusus menyelesaikan permasalahan yang sedang ditanganinya. Data dikumpulkan sendiri oleh penelti langsung dari sumber-sumber pertama atau tempat objek penelitian dilakukan yaitu : Kantor Kepala Desa dan Kantor Badan Pusat Statistik Kabupaten Musi Rawas.

b. Data sekunder adalah data yang diperoleh atau dikumpulkan oleh orang yang melakukan penelitian dari sumber-sumber yang tlah ada. Data ini digunakan untuk mendukung informasi primer yang telah diperoleh yaitu dari bahan pustaka, literatur, penelitian terdahulu, buku, dan lain sebagainya.

\subsection{Teknik dan prosedur pengumpulan data}

Teknik dan prosedur pengumpulan data merupakan kegiatan setelah data dari seluruh responden atau sumber data lain terkumpul. Kegiatan dalam analisis data adalah mengelompokan data berdasarkan variable dan jenis responden, mentabulasi data berdasarkan variable dari seluruh responden, menyajikan data tiap variable yang diteliti, melakukan perhitungan untuk menguji hipotesis yang telah diajukan Sugiyono (2014:147). Teknik pengumpulan data yang digunakan oleh peneliti adalah sebagai berikut : Observasi, Wawancara, Dokumentasi dan Triangulasi.

\subsection{Prosedur analisis data}

Analisis data merupakan proses pemecahan data menjadi komponenkomponen yang lebih kecil berdasarkan elemen dan struktur tertentu. Menurut Bogdan dan Biglen dalam Meleong. Analisis data kualitatif adalah upaya yang dilakukan dengan jalan bekerja dengan data, mengorganisasikan data, memilahmilah menjadi satuan yang dapat dikelola, mensintesiskan mencari dan menemukan pola, menemukan apa yang penting dan apa yang dipelajari dan memutuskan apa yang dapat diceritakan kepada orang lain. 


\subsection{Pemeriksaan keabsahan data}

Dalam pengujian keabsahan data, metode penelitian kualitatif menggunakan istilah yang berbeda dengan penelitian kualitatif adalah sebagai berikut : Perpanjang pengamatan, Meningkatkan ketekunan, Triangulasi, Analisis kasus negatif dan Menggunakan bahan referensi.

\subsection{Hasil Penelitian}

Berdasarkan penelitian yang telah dilakukan, didapatkan hasil penelitian sebagai berikut :

Tabel. 1

Hasil Wawancara Responden Penelitian Perbulan Juli 2018

\begin{tabular}{|c|c|c|c|c|c|c|c|c|c|}
\hline No & \multicolumn{9}{|c|}{ Data Hasil Penelitian } \\
\hline 1 & \multicolumn{9}{|c|}{ Sarana Kesehatan } \\
\hline & \multicolumn{9}{|c|}{ Pustu Bantuan Desa Petunang } \\
\hline 2 & \multicolumn{9}{|c|}{ Sarana Pendidikan } \\
\hline & \multicolumn{3}{|c|}{ SD } & \multicolumn{2}{|c|}{ SMP } & \multicolumn{2}{|c|}{ SMA } & \multicolumn{2}{|c|}{ PT } \\
\hline & \multicolumn{3}{|c|}{3} & \multicolumn{2}{|c|}{0} & \multicolumn{2}{|c|}{0} & \multicolumn{2}{|c|}{0} \\
\hline 3 & \multicolumn{9}{|c|}{ Jenis Kegiatan/organisasi Keagamaan } \\
\hline & \multicolumn{9}{|c|}{ Pengajian mingguan wanita } \\
\hline 4 & \multicolumn{9}{|c|}{ Penduduk Beragama } \\
\hline & \multicolumn{2}{|c|}{ Islam } & \multicolumn{3}{|c|}{ Kristen } & \multicolumn{2}{|l|}{ Hindu } & \multicolumn{2}{|l|}{ Budha } \\
\hline & Jumlah & $\%$ & Jum & \begin{tabular}{l|l} 
lah & \\
\end{tabular} & $\%$ & Jumlah & $\%$ & Jumlah & $\%$ \\
\hline & 2884 & 100 & \multicolumn{2}{|c|}{0} & $0 \%$ & 0 & $0 \%$ & 0 & $0 \%$ \\
\hline \multirow[t]{3}{*}{5} & \multicolumn{9}{|c|}{ Masyarakat Miskin } \\
\hline & \multicolumn{2}{|c|}{ Jumlah } & \multirow{2}{*}{\multicolumn{7}{|c|}{$\begin{array}{c}\% \\
154\end{array}$}} \\
\hline & \multicolumn{2}{|c|}{444} & & & & & & & \\
\hline \multirow[t]{3}{*}{6} & \multicolumn{9}{|c|}{ Kunjungan Warga ke Fasilitas Kesehatan } \\
\hline & \multicolumn{2}{|c|}{ Jumlah } & \multirow{2}{*}{$\begin{array}{c}\% \\
0.5\end{array}$} & & & & & & \\
\hline & 13 & & & & & & & & \\
\hline 7 & Pendidil & $\operatorname{an} \mathbf{T}$ & rakhir & & & & & & \\
\hline & & SD & & SN & MP & SN & & $\mathrm{PT}$ & \\
\hline & Jumlah & & $\%$ & Jumlah & $\%$ & Jumlah & $\%$ & Jumlah & $\%$ \\
\hline & 395 & & 8,9 & 46 & 10,3 & 3 & 0,8 & 0 & 0 \\
\hline
\end{tabular}




\begin{tabular}{|c|c|c|c|c|c|c|c|}
\hline No & \multicolumn{7}{|c|}{ Data Hasil Penelitian } \\
\hline 8 & \multicolumn{7}{|c|}{ Pendapatan } \\
\hline & \multicolumn{2}{|c|}{$\leq 1.000000$} & \multicolumn{2}{|c|}{$1000000-1500000$} & \multicolumn{2}{|c|}{$\geq 1500000$} & \\
\hline & Jumlah & $\%$ & Jumlah & $\%$ & Jumlah & $\%$ & \\
\hline & 83 & 18,7 & 361 & 81,3 & 0 & 0 & \\
\hline \multirow[t]{4}{*}{9} & \multicolumn{7}{|c|}{ Pengeluaran } \\
\hline & \multicolumn{2}{|c|}{$\leq 1.000000$} & \multicolumn{2}{|c|}{$1000000-1500000$} & \multicolumn{2}{|c|}{$\geq 1500000$} & \\
\hline & Jumlah & $\%$ & Jumlah & $\%$ & Jumlah & $\%$ & \\
\hline & 21 & 4,8 & 417 & 94 & 6 & 0,2 & \\
\hline \multirow[t]{2}{*}{10} & \multicolumn{7}{|l|}{ Kesehatan } \\
\hline & \multicolumn{7}{|c|}{ Tidak ada anggota keluarga yang sakit jasmani maupun Rohani } \\
\hline 11 & \multicolumn{7}{|c|}{ Pemenuhan Kebutuhan } \\
\hline & \multirow{3}{*}{\multicolumn{3}{|c|}{ Kebutuhan Primer }} & \multicolumn{4}{|c|}{ 1.Makan Dan Minum } \\
\hline \multirow[t]{2}{*}{ 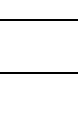 } & & & & 2.Pakaia & & & \\
\hline & & & & 3.Tempa & Tinggal & & \\
\hline & \multicolumn{3}{|c|}{ Kebutuhan Sekunder } & \multicolumn{4}{|c|}{ Tidak terpenuhi } \\
\hline & \multicolumn{3}{|c|}{ Kebutuhan Tersier } & \multicolumn{4}{|c|}{ Tidak terpenuhi } \\
\hline 12 & \multicolumn{7}{|c|}{ Kepemilikan Aset } \\
\hline & \multicolumn{7}{|c|}{ Memiliki tempat tinggal dengan kategori tempat tinggal keluarga miskin } \\
\hline
\end{tabular}

Berdasarkan tabel di atas pada Desa Petunang hanya memiliki 1 sarana kesehatan yaitu Puskesmas bantuan dan sarana Pendidikan hanya memiliki 3 buah bangunan Sekolah Dasar. Untuk kegiatan keagamaan, masyarakat Desa Petunang mengadakan pengajian mingguan di masjid setempat. Dan total jumlah penduduk Desa Petunang Kab. Musi Rawas berjumlah 2884 jiwa. Sebanyak 15,4\% dari total jumlah penduduk Desa Petunang adalah masyarakat miskin yaitu berjumlah 444 jiwa. Dari 444 jiwa penduduk miskin yang diteliti, sebagian besar dari jumlah tersebut berpendidikan Sekolah Dasar, yaitu sebanyak 395 orang atau sebesar $88,9 \%$. sedangkan masyarakat yang berpendidikan SMP dan SMA hanya berjumlah 46 orang atau 10,3\% dan SMA 3 orang atau 0,8\%. Data ini menunjukan bahwa penduduk miskin Desa Petunang memiliki pendidikan yang rendah. Dari 444 jiwa penduduk miskin yang di teliti. Sebagian besar jumlah tersebut memiliki pendapatan antara 1.000.000-1.500.000 sebanyak 361 orang atau $81,3 \%$.Dan 83 orang atau $18,7 \%$ tersebut memiliki pendapatan di bawah 1.000.000. dari jumlah penduduk miskin yang diteliti memiliki pengeluaran lebih dari 1.500.000 sebanyak 6 orang atau sebesar $0,2 \%$, dan yang memiliki pengeluaran 1.000.000-1.500.000 sebesar 417 orang atau 94\%, dan sisanya memiliki pengeluaran di bawah 1.000 .000 sebesar 21 orang atau 4,8\%. Data pendapatan dan pengeluaran ini menunjukan bahwa penduduk Desa Petunang memiliki pendapatan yang lebih kecil dari pada pengeluarannya. 
Data-data tabel diatas mengindikasikan bahwa memang terdapat hubungan antara kualitas sumber daya manusia dengan kemiskinan di Desa Petunang. Hubungan-hubungan tersebut akan dibahas pada bab selanjutnya.

\section{PEMBAHASAN}

Hubungan antara kualitas sumber daya manusia dan kemiskinan di desa petunang dijelaskan sebagai berikut :

\subsection{Hubungan Kualitas Sumber Daya Manusia dan Pendapatan di Desa Petunang Kabupaten Musi Rawas}

Kualitas sumber daya manusia dan pendapatan adalah dua faktor yang saling mempengaruhi. Seseorang dengan Kualitas sumber daya manusia yang baik akan menghasilkan Pendapatan yang baik sebaliknya. Menurut penelitian Wikananda Gede dalam Sendow (2015:5) mengatakan bahwa tingkat pendapatan sangat berhubungan dengan kualitas hidup seseorang. Seseorang yang berpenghasilan kurang memiliki kualitas hidup yang rendah.

\subsection{Hubungan Kualitas Fisik dan Pendapatan di Desa Petunang Kabupaten Musi Rawas}

Kualitas fisik akan menentukan aktifitas fisik seseorang seseorang yang memiliki aktifitas fisik yang tinggi akan menunjukkan produktifitas yang tinggi pula sehingga pendapatan juga akan tinggi. Menurut Survey dari World Health Organization (WHO) menyatakan bahwa, secara global yang tidak cukup aktif dalam melakukan aktivitas fisik yaitu sekitar 1 dari 4 orang dewasa. Pada tahun 2010 orang dewasa yang berusia lebih dari 18 tahun ada sekitar 23\% yang tidak cukup aktif dalam melakukan aktivitas fisik, pada negara-negara yang berpenghasilan rendah sekitar 26\% laki-laki dan 35\% perempuan kurang aktif dalam melakukan aktivitas fisik, sedangkan di negara-negara berpenghasilan rendah ada sekitar $12 \%$ laki-laki dan $24 \%$ perempuan yang aktif dalam melakukan aktivitas fisik. Pada remaja di dunia lebih dari $80 \%$ yang kurang aktif dalam melakukan aktivitas fisik (WHO, 2017).

Kondisi fisik sumber daya manusia Desa Petunang menunjukan kondisi fisik yang baik sehingga dapat bekerja dengan baik sebagai petani dan buruh tani tetapi berbanding terbalik dengan penghasilannya. Hal ini mungkin dipengaruhi oleh faktor-faktor lain seperti kepemilikan lahan tempat bekerja sehingga pendapatan yang dihasilkan dalam bekerja dibagi lagi dengan pemilik lahan. Hal ini mengakibatkan pendapatan mereka tetap rendah walaupun kualitas fisik sumber daya manusianya baik.

\subsection{Hubungan Kualitas Non Fisik dan Pendapatan di Desa Petunang Kabupaten Musi Rawas}

Aspek kualitas non fisik sumber daya manusia yang dianalisis dalam penelitian ini antara lain kualitas intelektual dan kualitas Spriritual. 


\subsection{Hubungan Kualitas Intelektual Dan Pendapatan Desa Petunang Kabupaten Musi Rawas}

Pendidikan merupakan salah satu cara untuk meningkatkan kualitas Intelektual sumber daya manusia. Melalui pendidikan, pengetahuan seseorang akan bertambah yang akan bermanfaat untuk mempelajari keterampilan yang berguna di dunia kerja. Dengan demikian pendidikan dapat dimasukkan sebagai investasi pembangunan yang hasilnya dapat dinikmati di kemudian hari. Sebagaimana pembangunan di bidang lain, pendidikan menjadi salah satu bidang utama selain kesehatan dan ekonomi (BPS, 2013). Pendidikan merupakan salah satu cara untuk meningkatkan kualitas intelektual seseorang, melalui pendidikan dan pengetahuan seseorang akan mempunyai keahlian dan intelektual yang tinggi. Sehingga pendapatan akan tinggi juga.

Kondisi intelektual masyarakat Desa Petunang menunjukan kondisi intelektual yang tidak baik, itu di buktikan dengan masih banyaknya masyarakat yang pendidikan terakhirnya hanya sebatas Sekolah Dasar yang berjumlah 395 atau 88,9\% dan yang berpendidikan Sekolah Menengah Pertama berjumlah 46 atau $10,3 \%$ dan yang berpendidikan Sekolah Menengah Atas berjumlah 3 atau 0,8\%. Hal ini mengakibatkan masyarakat Desa Petunang banyak yang tidak mempunyai keterampilan dan hal itu akan membuat rata-rata pendapatan responden Desa Petunang tetap rendah. Menurut (BPS, 2013)Pendidikan merupakan salah satu cara untuk meningkatkan kualitas sumber daya manusia. Melalui pendidikan, pengetahuan seseorang akan bertambah yang akan bermanfaat untuk mempelajari keterampilan yang berguna di dunia kerja. Dengan demikian pendidikan dapat dimasukkan sebagai investasi pembangunan yang hasilnya dapat dinikmati di kemudian hari. Sebagaimana pembangunan di bidang lain, pendidikan menjadi salah satu bidang utama selain kesehatan dan ekonomi.

Pendidikan memiliki peran penting dalam mengurangi kemiskinan baik di Negara Indonesia atau negara manapun dalam jangka panjang. Baik secara tidak langsung melalui perbaikan produktivitas dan efisiensi secara umum, maupun secara langsung melalui pelatihan golongan miskin dengan keterampilan yang dibutuhkan untuk meningkatkan produktivitas mereka dan pada waktunya akan meningkatkan pendapatan mereka (Arsyad, 2014).

Penelitian yang dilakukan Appleton (2001) menjelaskan bahwa kemiskinan yang terjadi di Uganda selama beberapa periode menjadikan kehidupan masyarakatnya terpuruk.Namun itu semua berakhir setelah adanya peningkatan tingkat pendidikan masyarakat. Dengan peningkatan pendidikan di sana membuat kehidupan masyarakat Uganda lebih berarti. Mereka memperoleh pekerjaan yang layak dengan upah yang sebanding.Sehingga mereka mampu meningkatkan kesejahteraan hidup mereka yang berdampak pada menurunnya kemiskinan. Hasil penelitian yang sama juga dikemukakan oleh Doshi (2012) yang menyatakan bahwa pendidikan dapat mengurangi kemiskinan secara langsung yaitu dengan meningkatkan produktivitas bagi golongan miskin, memperbaiki kesempatan mereka untuk memperoleh pekerjaan dengan upah yang lebih baik. Dengan demikian pendidikan dapat mengurangi jumlah penduduk miskin yang ada.Tingkat pendidikan menjadi faktor penting yang mempengaruhi kemiskinan. Karena tingkat pendidikan akan mempengaruhi distribusi pendapatan yang pada 
akhirnya akan juga mempengaruhi kemiskinan. Jika semakin tinggi tingkat pendidikan maka distribusi pendapatan akan merata sehingga kemiskinan bisa berkurang.

\subsection{Hubungan Kualitas Spiritual Dan Pendapatan Desa Petunang Kabupaten Musi Rawas}

Menurut kavri dalam jurna uripah (2018 : 4) Manusia bukan semata-mata mahluk rasional tetapi juga mahluk spiritual. Sebagai mahluk rasional, maka dia akan memperhitungkan pendapatan finansialnya dalam mengatur gaya hidup dan pola konsumsinya agar tidak mengalami "besar pasak dari pada tiang”. Sebagai mahluk yang mempunyai kecerdasan spiritual, orang tersebut akan mengarahkan gaya hidup, juga pola konsumsinya agar hidupnya menjadi tenang dan dia dapat menikmati hidup. Kecerdasan spiritualnya akan membimbingnya untuk bisa menyukuri apa yang telah diperolehnya.

Kualitas spiritual Desa Petunang menunjukan spiritual desa petunang menunjukkan kondisi yang buruk, hal ini terbukti sedikitnya organisasi atau kegiatan keagamaan yang diadakan untuk memperbaiki kualitas spiritual penduduk desa petunang. desa petunang hanya mempunyai pengajian wanita yang hanya di adakan 1 minggu sekali . dan tidak ada remaja masjid di lingkungan desa petuang. Dengan konsisi yang seperti ini mengakibatkan penduduk miskin Desa Petunang tidak mampu untuk mengatur gaya hidup dan pola konsumsinya sehingga mengakibatkan banyak penduduk yang mengalami "besar pasak dari pada tiang". Seseorang dengan kecerdasan spiritual yang baik akan memiliki keimanan yang kuat untuk bersikap hidup hemat dalam gaya hidup dan pola konsumsi walaupun dengan pendapatan yang kecil sehingga kebutuhannya tetap terpenuhi.

\subsection{Hubungan Kualitas Sumber Daya Manusia, Pengeluaran Dan Pemenuhan Kebutuhan Di Desa Petunang Kabupaten Musi Rawas}

Kualitas Sumber daya manusia, pengeluaran dan Pemenuhan kebutuhan merupakan aspek yang saling mempengaruhi. Seseorang dengan Kualitas Sumber daya manusia yang baik akan mampu mengelola pengeluaran dengan baik untuk memenuhi kebutuhannya. Kualitas sumber daya manusi yang baik akan mampu untuk memprioritaskan penggunaan biaya pengeluaran untuk pemenuhan kebutuhan sesuai dengan tingkatan kepentingannya.

\subsection{Hubungan Kualitas Fisik Sumber Daya Manusia, Pengeluaran Dan Pemenuhan Kebutuhan di Desa Petunang Kabupaten Musi Rawas}

Berdasarkan Tabel.1 Mengindikasikan penduduk miskin di Desa Petunang mempunyai kondisi fisik yang baik. Kualitas fisik yang baik harus di dukung oleh pemenuhan kebutuhan yang tercukupi, terutama kebutuhan primer. Artinya masyarakat Desa Petunang tetap mampu mengelolah pengeluaran dengan baik untuk memenuhi kebutuhan primer sehingga tetap memiliki kualitas fisik yang baik, walaupun mempunyai pendapatan yang kecil. 


\subsection{Hubungan Kualitas Non Fisik Sumber Daya Manusia Terhadap Pengeluaran}

Berdasarkan Tabel.1 keadaan masyarakat miskin Desa Petunang sebagian besar berpendidikan SD, berpendidikan rendah mengakibatkan kualitas intelektual penduduk miskin Desa Petunang juga rendah, sehingga dengan kondisi intelektual yang rendah penduduk miskin Desa Petunang hanya mampu berfikir tentang cara pengeluaran untuk memenuhi kebutuhan pokok saja. Sebenarnya walaupun dengan pendapatan yang kecil seseorang dengan kualitas intelektual yang tinggi akan mampu untuk mengelola pengeluaran dengan baik misalnya tetap menyisikan biaya pengeluaran untuk menabung dan nantinya uang tabungan tersebut dapat mampu memperbaiki kualitas hidup mereka, tetapi hal seperti ini tidak terjadi pada penduduk miskin di Desa Petunang.

Sebagai mahluk yang mempunyai kecerdasan spiritual, seseorang akan mengarahkan gaya hidup, juga pola konsumsinya agar hidupnya menjadi tenang dan dia dapat menikmati hidup. Kondisi kualitas spiritual yang buruk mengakibatkan penduduk miskin Desa Petunang tidak mempunyai keimanan untuk berperilaku hemat dalam konsumsi sehingga pengeluaran tetap besar.

\subsection{Hubungan Kualitas Sumber Daya Manusia Terhadap Kesehatan Desa Petunang Kabupaten Musi Rawas}

Salah satu indikator meningkatknya kualitas sumber daya manusia adalah dengan melihatseberapa tinggi derajat kesehatan masyarakat Faktor yang mempengaruhi kualitas sumber daya manusia antara lain adalah faktor kesehatan. faktor ini penting karena seseorang tidak mampu mengembangkan kapasitasnya secara maksimal apabila yang bersangkutan tidak memiliki status kesehatan yang optimal. (Depkes RI, 2013).

Dengan memiliki sarana kesehatan yang minim Desa Petunang tetap mampu mewujudkan masyarakat yang sehat. Hal ini terlihat dari sedikitnya jumlah masyarakat sakit yang mengunjungi sarana kesehatan yang berupa pustu tersebut.

\subsection{Hubungan Kualitas Fisik Sumber Daya Manusia Terhadap Kesehatan di Desa Petunang Kabupaten Musi Rawas}

Tabel.1 menunjukkan kualitas fisik masyarakat Desa Petunang dalam kondisi yang baik, termasuk penduduk miskinnnya. Dengan memiliki kualitas fisik yang baik penduduk Desa Petunang tetap mampu melakukan aktifitas fisik dengan baik dalam bekerja dan kegiatan sehari-hari sehingga mampu menjaga kesehatannya. Menurut Russell (2013), .aktivitas fisik adalah segala macam gerak yang membutuhkan energi. Aktivitas fisik secara teratur telah lama dianggap sebagai komponen penting dari gaya hidup sehat.

\subsection{Hubungan Kualitas Non Fisik Sumber Daya Manusia dan Kesehatan Desa Petunang Kabupaten Musi Rawas}

Kualitas intelektual yang rendah mengakibatkan penduduk miskin di Desa Petunang menerapkan pola hidup yang sederhana artinya masyarakat menerapkan gaya hidup yang tidak macam- macam seperti misalnya dalam mengkonsumsi makanan. Penduduk miskin hanya berfikir untuk mengkonsumsi makanan- 
makanan pokok saja. Keadaan intelektual yang rendah membuat masyarakat berfikir untuk tidak menghabiskan uang untuk mengkonsumsi makanan yang merusak kesehatan misalnya fast food, junk food yang dapat merusak kesehatan.Pola hidup sehat selalu berhubungan dengan faktor makanan yang menyehatkan serta menjauhi pola makanan tidak sehat yang nantinya akan menyebabkan hari - hari kita menjadi suram karena timbulnya penyakit.

Kualitas spiritual yang baik akan mempengaruhi pola hidup yang baik dan mempunyai kesehatan yang baik juga. Kualitas spiritual yang baik akan menjaga kebersihan dikarenakan kebersihan sebagian dari iman. Tetapi itu berbanding terbalik dengan keadaan di desa petunang, penduduk miskin Desa Petunang mempunyai kualitas spiritual yang kurang baik. Itu di buktikan dari data tabel.1 kegiatan keagamaan Desa Petunang hanya mempunyai 1 kegiatan keagamaan. Akan tetapi walaupun kualitas spiritual penduduk miskin Desa Petunang kurang baik, tetapi kesehatan penduduk miskin di Desa Petunang sangat baik itu terbukti dari tabel.1. di karenakan di Desa Petunang masih banyak tumbuh-tumbuhan segar yang dapat di konsumsi dan di Desa Petunang masih mempunyai udara yang segar karena polusi udara yang di akibatkan oleh polusi kendaraan dan polusi pabrik masih sedikit. Hal inilah yang mengakibatkan walaupun kualitas spiritual penduduk miskin Desa Petunang kurang baik tetapi mereka mempunyai kesehatan yang baik.

\subsection{Hubungan Kualitas Sumber Daya Manusia dan Kepemilikan Aset Desa Petunang Kabupaten Musi Rawas}

Rendahnya kualitas sumber daya manusia penyebab penduduk miskin tidak mempunyai kepemilikan aset. Hal ini terbukti pada tabel.1 yang menyatakan penduduk miskin Desa Petunang hanya berpendidikan Sekolah Dasar berarti dapat dilihat bahwa penyebab penduduk miskin Desa Petunang hanya memiliki aset tempat tinggal dengan kategori tempat tinggal keluarga miskin dan tidak memiliki aset pribadi lainnya hal ini di sebabkan oleh rendahnya kualitas sumber daya manusia yang ada di Desa Petunang Kabupaten Musi Rawas.

\subsection{Hubungan Kualitas Fisik Sumber Daya Manusia dan Kemilikan Aset Desa Petunang Kabupaten Musi Rawas}

Tabel.1 menjelaskan kualitas fisik sember daya manusia Desa Petunang dalam kondisi fisik yang baik, termaksud penduduk miskin Desa Petunang. Dengan memiliki kondisi fisik yang baik penduduk miskin Desa Petunang tetap mampu melakukan aktivitas fisik dalam bekerja sebagai petani dan buruh tani. Hal ini berbanding terbalik dengan kepemilikan aset, walaupun kualitas sumber daya manusia Desa Petunang dalam kondisi baik penyebab penduduk miskin Desa Petunang tidak mempunyai kepemilikan aset dikarenakan pendapatan penduduk miskin Desa Petunang Kabupaten Musi Rawas yang rendah.

\subsection{Hubungan Kualitas Non Fisik Sumber Daya Manusia dan Kepemilikan Aset Desa Petunang Kabupaten Musi Rawas}

Kualitas intelektual yang rendah mengakibatkan penduduk miskin Desa Petunang tidak mempunyai kepemilikan aset pribadi. Dikarenakan pendidikan 
salah satu cara untuk meningkatkan kualitas intelektual penduduk miskin di Desa Petunang. Jika pendidikan penduduk miskin Desa Petunang tinggi maka kualitas intelektual juga akan tinggi dan penduduk miskin Desa Petunang akan mendapatkan pekerjaan dengan pendapatan yang tinggi juga, agar dapat memiliki kepemilikan aset. Hal ini berbanding terbalik dengan keadaan pendidikan dan kualitas intelektual penduduk miskin Desa Petunang Kabupaten Musi Rawas hal ini tertera pada tabel.1, yang menjelaskan keadaan pendidikan dan kualitas intelektual penduduk miskin Desa Petunang hanya mampu berpendidikan Sekolah Dasar. Dengan berpendidikan Sekolah Dasar penduduk miskin Desa Petunang hanya mampu bekerja sebagai petani dan buruh tani dengan pendapatan yang hanya mampu membeli kebutuhan pokok sehari-hari dan tidak dapat mempunyai kepemilikan aset dengan pendapatan yang minim.

Dengan kualitas spiritual yang rendah maka penduduk miskin Desa Petunang tidak akan mempunyai iman yang kuat dan tekat yang kuat untuk tetap berusaha agar dapat mempunyai kepemilikan aset dan dengan kualitas spiritual penduduk miskin Desa Petunang Kabupaten Musi Rawas yang rendah itu dapat menyebabkan penduduk miskin Desa Petunang Kabupaten Musi Rawas cepat putus asa dan pasrah dengan keadaan yang akan terus berjalan di bawah garis angka kemiskinan.

\section{SIMPULAN DAN REKOMENDASI}

\subsection{Simpulan}

Kualitas sumber daya manusia dalam menekan angka kemiskinan di Desa Petunang Kabupaten Musi Rawas adalah bahwa kualitas sumber daya manusia penduduk miskin Desa Petunang memang sangatlah buruk untuk dapat menekan angka kemiskinan yang terjadi di Desa Petunang hal ini dilihat dari beberapa aspek antara lain sebagai berikut :

1. Kondisi fisik sumber daya manusia Desa Petunang menunjukan kondisi fisik yang baik sehingga dapat bekerja dengan baik sebagai petani dan buruh tani tetapi berbanding terbalik dengan penghasilannya. Hal ini mungkin dipengaruhi oleh faktor-faktor lain seperti kepemilikan lahan tempat bekerja sehingga pendapatan yang dihasilkan dalam bekerja dibagi lagi dengan pemilik lahan. Hal ini mengakibatkan pendapatan mereka tetap rendah walaupun kualitas fisik sumber daya manusianya baik.

2. Masyarakat di Desa Petunang memiliki tingkat Pendidikan yang rendah. Terbukti masih banyaknya masyarakat yang rata-rata umurnya 40-50 keatas yang hanya lulusan SD, dan masyarakat yang rata-rata umurnya 20-30 hanya lulusan SMP-SMA, bahkan tidak Sekolah. Dari 17 responden, lulusan SD lebih banyak di bandingkan dengan lulusan yang lain. Sebanyak 9 responden hanya lulusan SD. Lulusan SMP sebanyak 1 responden. Lulusan SMA/Sederajat sebanyak 5 responden. Lulusan S1/perguruan tinggi sebanyak 1 responden.

3. Kualitas spiritual Desa Petunang Kabupaten Musi Rawas menunjukan spiritual desa petunang menunjukkan kondisi yang buruk, hal ini terbukti sedikitnya organisasi atau kegiatan keagamaan yang diadakan untuk memperbaiki kualitas spiritual penduduk desa petunang. desa petunang 
hanya mempunyai pengajian wanita yang hanya di adakan 1 minggu sekali . dan tidak ada remaja masjid di lingkungan desa petuang. Dengan konsisi yang seperti ini mengakibatkan penduduk miskin Desa Petunang Kabupaten Musi Rawas tidak mampu untuk mengatur gaya hidup dan pola konsumsinya sehingga mengakibatkan banyak penduduk yang mengalami "besar pasak dari pada tiang". Seseorang dengan kecerdasan spiritual yang baik akan memiliki keimanan yang kuat untuk bersikap hidup hemat dalam gaya hidup dan pola konsumsi walaupun dengan pendapatan yang kecil sehingga kebutuhannya tetap terpenuhi.

\subsection{Rekomendasi}

Beberapa permasalahan yang belum terpecahkan sehingga mengajukan beberapa saran-saran tersebut antara lain :

1. Peran kualitas sumber daya manusia sangat berpengaruh dalam menekan angka kemiskinan sehingga untuk kualitas sumber daya manusia yang ada di Desa Petunang Kabupaten Musi Rawas harus di tingkatkan lagi agar lebih baik.

2. Pendidikan harus diutamakan karena pendidikan menjadi peran penting untuk meningkatkan kualitas sumber daya manusia agar dapat menekan angka kemiskinan di Desa Petunang Kabupaten Musi Rawas.

3. Kualitas spritual harus dihidupkan lagi agar masyarakat Desa Petunang Kab. Musi Rawas mempunyai iman yang baik serta harus tetap bersyukur.

4. Perbaiki lagi untuk kreatif masyarakat miskin Desa Petunang Kabupaten Musi Rawas agar warga miskin Desa Petunang dapat berkreatifitas untuk meningkatkan taraf hidup mereka.

5. Untuk pemerintah setempat agar sering memberikan sosialisasi untuk usaha agar warga miskin Desa Petunang Kabupaten Musi Rawas bisa membuka usaha dan tau dasar-dasar untuk usaha yang baik.

6. Pemerintahan agar segera membuat kegiatan-kegiatan yang bersifat untuk meningkatkan kualitas sumber daya manusia yang ada di Desa Petunang Kabupaten Musi Rawas.

\section{DAFTAR PUSTAKA}

Arsyad L. (2014) Ekonomi Pembangunan, Kualitas Intelektual Terhadap Pendidikan, UPP STIMK YKPN, Universitas Gadjah Mada.

Appleton, Simon. 2001. Education, Income and Poverty in Uganda. Credit Research Paper, Vol. 1, No. 2, (PP: 5-20).

Arsyad, Lincolin. 2016. Ekonomi Pembangunan edisi ke 5. Universitas Gajah Mada: UPP STIM YKPN.

Kadji, Yulianto 2017. Kemiskinan dan Konsep Teoritisnya. UNGPRES: Makassar Mulyadi, 2014. Ekonomi Sumber Daya Manusia Dalam Perspektif Pembangunan. Edisi Revisi. Jakarta: PT Raja Grafindo Persada.

Ndraha, T. 2015. Pengantar Teori Pengembangan Sumber Daya Manusia.Jakarta: PT. Rineka Cipta.

Salim, Emil. 2014. Aspek Sikap Mental dalam Manajemen sumber Daya Manusia. Jakarta: Ghalia Indonesia. 
Soekidjo Notoatmodjo. 2017. Pengembangan Sumber Daya Manusia. Jakarta: PT. Rineka Cipta.

Sugiyono. (2014). Metode Penelitian Pendidikan Pendekatan Kuantitatif, Kualitatif, dan R\&D. Bandung: Alfabeta.

Sendow. (2015). Hubungan Kualitas Usmber Daya Manusia Dan Pendapatan, Jakarta: Erlangga.

Uripah, (2018), Kualitas Spiritual Terhadap Pendapatan, Jurnal Ekonomi. Jakarta Selatan. 